\title{
Health Workers' Legal Protection Policy to the Coronavirus Disease 19 (Covid-19) Containment Measures
}

\author{
Helmi $^{1}$, Hafrida ${ }^{2}$, Retno Kusniati ${ }^{3}$ \\ ${ }^{1}$ Universitas Jambi, Indonesia, helmi@unja.ac.id \\ ${ }^{2}$ Universitas Jambi, Indonesia, hukum@unja.ac.id \\ ${ }^{3}$ Universitas Jambi, Indonesia, kusniati@unja.ac.id
}

Submitted: October 22, 2020; Reviewed: November 4, 2020; Accepted: December 3, 2020

\begin{tabular}{ll}
\hline \multicolumn{1}{c}{ Article Info } & \multicolumn{1}{c}{ Abstract } \\
\hline Keywords: & $\begin{array}{l}\text { This research aims to analyze protection policies for } \\
\text { Health Workers, Legal Frame } \\
\text { Work, COVID-19. }\end{array}$ \\
holth workers amidst COVID-19. Through statute \\
approach and based on the rights theory, this study \\
examines legal development, or legal framework is \\
needed to formulate and to protect health worker. \\
Since the COVID-19 outbreak spreads quickly and \\
massively, Health worker is at the forefront of \\
handling COVID-19, but they are also vulnerable to \\
get infected by the virus. Some cases showed that \\
many health workers tested positive after providing \\
health services. The findings of the research showed \\
that the right of medical workers to get personal \\
protective equipment and safety guarantees were not \\
enough to protect them. On the other hand, the \\
community was still ignoring the risk of this disease \\
and broke the health protocol in the public place. \\
Health workers can perform their job effectively if \\
people are in healthy condition and do not need to \\
go to the hospital. To containment measures of the \\
COVID-19 State has to choose one of the effective \\
ways to protect people and health workers by \\
regulating and giving a penalty to the perpetrators \\
of the COVID-19 protocol.
\end{tabular}

\section{A. Introduction}

Health workers are under tremendous and heavy pressure during the national disaster ${ }^{1}$ Response to the pandemic Coronavirus Disease (from now on referred to as Covid-19), an infectious outbreak for which no vaccine has yet been found. Various problems are faced from lack of protective clothing

\footnotetext{
${ }^{1}$ Presidential Decree 12/2020 concerning Non-natural National Disasters, Coronavirus disease (COVID-19).
} 
(Personal Protective Equipment/PPE), limited rest time, fatigue, changes in relationships with patients, colleagues and family and dishonesty of patients with their travel history when carrying out examinations, including being rejected when returning to their home and vulnerable health workers should face the infection. ${ }^{2}$

Thousands of medical personnel in Italy, Spain and the United States have been exposed to Covid $-19^{3}$. This pandemic shows that casualties have not only hit the community (patients) but also have endangered and claimed health workers who are struggling on the front lines in overcoming the spread of the disease. On the other hand, developments in Indonesia, Covid-19 cases continue to increase, a rapid development from April to 6,248 people on 19 April 2020 to now on 13 September 2020 has reached 218,382 people. This certainly has implications for the readiness, strength and safety of health workers, the more positive, the higher burden and pressure of health workers in the Covid-19 health services, and the more their safety is threatened. In August 2020, the number of health workers who died due to Covid-19 reached 104 people. $^{4}$

This condition clearly cannot be ignored since new cases keep on appearing. Meanwhile, health workers on duty are vulnerable to infection. According to Jatu Apridasari, in terms of affordability, there are five groups most susceptible to contracting the virus as follows: ${ }^{5}$

1. Health workers ${ }^{6}$ who handle patients, people who live in the same house as Covid-19 sufferers;

2. People travelling in one means of transportation;

3. Caring person and waiting for the patient in the room;

4. Guests who are in the same room with sufferers Covid-19; and

5. People who work together with sufferers of Covid-19.

\footnotetext{
2 https://www.tempo.co/bbc/5990/kisah-tenaga-kesehatan-yang-hadapi-wabah-virus-coronadi-empat-negara-maju-bagaimana-kami-tidak-takut, Accessed on 19 April 2020.

${ }^{3}$ Starting from the city of Wuhan, China, a new type of coronavirus called COVID-19 has spread to various countries in the world and has caused the outbreak of COVID-19 around the world. On 11 March 2010, the World Health Organization (WHO) declared COVID-19 a pandemic. See Hoa Jin et al., "Complex Emergency of Covid 19 Management and Experience in Zhuhai China", International Journal Antimicrobacterial Agent 55, no. 5 (2020): 105961, 105962, DOI: 10.1016/j.ijantimicag.2020.105961, see also Rajib Shaw et al., "Governance, Citizen and Behaviour in Pandemic Lesson from east Asia", Journal Progress in Disaster Science 6, (2020):10009, DOI: 10.1016/j.pdisas.2020.100090.

4 https://www.kompas.com/tren/read/2020/09/05/080400265/daftar-10-negara-dengan-kasuskematian-tenaga-medis-tertinggi-di-dunia?page=all, Accessed on19 April 2020.

5 https://www.kompas.com/tren/read/2020/03/06/173000265/infografik--6-kelompok-orangyang-rentan-terinfeksi-virus-corona, Accessed on19 April 2020.

6 "A health worker is defined as any person who devotes himself to the health sector and has the knowledge and /or skills according to education in the health sector which for certain types requires the authority to carry out health efforts (Article 1 number 1 of Law Number 34 of 2014 on Health Workers)."
} 
Judging from the vulnerability of transmission, health workers are the party with the highest level of risk. What are the regulations for the protection of health workers on duty amid a pandemic danger? "The provisions of Article 50 of Law Number 29 of 2004 concerning Medical Practice specify that:

1. In practising medicine, a doctor or dentist has the right to obtain legal protection as long as he carries out his duties following professional standards and standard operating procedures.

2. In practising medicine, a doctor or dentist has the right to provide health services according to professional standards and standard operating procedures."

Concerning the rights of health workers regulated in the Health Law in Article 57, it confirms that: "In carrying out the practice, the health worker has the right":

1. Obtaining legal protection as long as carrying out tasks under Professional Service Standards and Standard Operating Procedures.

2. Obtaining complete and correct information from Health Care Recipients or their families.

3. Receiving fees for services.

4. Obtaining protection for occupational safety and health, treatment under human dignity, morals, morals, and religious values.

5. Getting the opportunity to develop their profession.

6. Refusing the wishes of Health Service Recipients or other parties that are contrary to Professional Standards, code of ethics, service standards, Standard Operating Procedures, or provisions of laws and regulations, and

7. The other rights under the provisions of the Laws and Regulations.

In connection with the problem of exposure of health workers to Covid-

19, China recorded 3,400 health workers exposed, while 2,692 Italian health workers are reported to have been infected with Covid-19. In other parts of the world, in the United States, a survey by National Nurses United (2020) showed that 44 per cent of health workers said that health facilities (health facilities) provide information to identify potential cases of Covid-19. However, only 19 per cent of the 6,500 nurses from 48 states know if their health facilities have the policy to deal with problems if health workers are potentially exposed to the virus. As for Indonesia, based on publications from print and electronic media, it is known that there are 46 health workers from dr. Kariadi in Semarang Hospital positive for Covid-197, while in Jakarta, 161 health workers are exposed. ${ }^{8}$

\footnotetext{
7 https://www.kompas.com/tren/read/2020/04/17/155100565/46-tenaga-kesehatan-disemarang-positif-covid-19-ini-harapan-persatuan-perawat-?page=all, Accessed on 17 April, 2020.

8 https://www.liputan6.com/news/read/4224721/161-tenaga-kesehatan-di-jakarta-positifcovid-19, Accessed on 17 April, 2020
} 
Meanwhile, according to the Indonesian Doctors Association until September 2020, 228 health workers had died. The vulnerability of health workers during the Covid-19 pandemic needs attention from the government as the policymaker. In addition to Covid-19, being a contagious epidemic, health workers are also suffering from fatigue which lowers the immune system making it more vulnerable than usual. In various countries, the protection of health workers has also become an important policy. For example, a quarantine system has been put in place to stop diseases, which will make it easier for health workers to carry out their mission.

"Millennia societies have separated individuals (livestock and goods) to stop the spread of disease, lay discourse, as well as in American law. This practice is often called "quarantine". Contemporary public health practice, however, distinguishes between different forms of enforced separation of individuals, and preserves the term quarantine for the separation of individuals or groups who are not ill but are thought." 9

In the global forum, the World Health Organization (WHO) emphasized that countries must carry out restrictions in order to prevent the spread of the pandemic so that countries, especially health workers, can prepare and have the ability to deal with infected outbreaks and the rate of cases can be reduced.

"The existence of WHO aims to 'prevent, protect against, control and provide a public health response to the international spread of disease in ways that are commensurate with and restricted to public health risks, and avoids unnecessary interference with international traffic and trade. The WHO's advice based on many years of international outbreak response was considered by many to be reasonable and evidence-based the recommendation on travel restrictions in the face of the rapid spread of COVID-19 among countries." 10

Furthermore, WHO through the legal instrument International Health Regulation in 2005 which has been agreed upon and applied in the provisions of Article 43 and Article 45 states "to govern how 196 countries and WHO collectively address the global spread of disease and avoid unnecessary interference with international traffic and trade. Article 43 of this legally binding instrument restricts the measures countries can implement when addressing public health risks to those measures that are supported by science, commensurate with the risks involved, and anchored in the human right".

Under the provisions of Article 43 of the IHR as a binding international legal instrument limiting actions, it can be applied by the State when dealing with public health risks with parameters of action supported by science, commensurate with the risks involved, and following human rights. This

\footnotetext{
${ }^{9}$ Wendy E. Parmet, Quarantining the law of quarantine: why quarantine law does not reflect current constitutional law(2018), 6.

10 Eskild Petersen et al., "Covid-19 Travel Restriction and The International Health Regulation", International Journal of Infectious Diseases 94, (2020): 88-90, 90, DOI: 10.1016/j.ijid.2020.04.029 1201-9712/Crown.
} 
regulation does not deter the State, states parties implement health measures, under their relevant national laws and obligations under international law, in addressing public health risks or health emergencies of international concern but should be under human rights. In this context, it is related to the rights of patients, the rights of health workers and the rights of the community during a pandemic. ${ }^{11}$

The right to health does not mean that the State provides expensive health service facilities but hopes the Government and Local Governments to formulate and implement policies that lead to the fulfilment of fundamental rights to health for all people, including making policies ensured that health workers carry out tasks safely and protected in times of dangerous outbreaks.

Furthermore, concerning human rights-based policies, the provisions of Law Number 39 of 1999 concerning Human Rights Article 8 affirm the obligations and responsibilities of the government in protecting, respecting and fulfilling human rights in conjunction with Article 71 . These emphasize that the government is obliged and responsible to respect, protect, enforce, and promote human rights as regulated in this law, other laws and regulations, and international human rights law accepted by the Republic of Indonesia. Then, the provisions of Article 72 also stipulate that the obligations and responsibilities of the government as referred to in article 71 include practical implementation steps in the fields of law, politics, economy, social, culture, national defence and security and other fields.

Questions such what are the rights of health workers to care for Covid-19 patients with the high risk infected when they treat them? Do health workers have the right to refuse to treat Covid-19 positive patients or Do they have a professional obligation to treat patients no matter how high the risk to health workers, including with limited personal protective equipment? In the policy framework, both the central and regional governments are duty bearers or parties that have the authority to seek all forms of policies and budgets in implementing guarantees regarding protection, to respect, and to fulfil against human rights, especially the rights of health workers. Law as a means of development refers to the goal of the establishment of the State ${ }^{12}$ To protect all of Indonesia's blood spills and to create welfare and social justice. This means that the legal policies that will be taken regarding the Covid-19 epidemic should be able to protect all citizens, especially health workers as the most vulnerable group working in situations that are at risk of exposure.

\footnotetext{
${ }^{11}$ Article 45 International Health Regulation: "These Regulations shall not preclude States Parties from implementing health measures, in accordance with their relevant national law and obligations under international law, in response to specific public health risks or public health emergencies of international concern."

12 Bernard Arief Sidharta, Refleksi tentang Struktur Ilmu Hukum (Bandung: MandarMaju, 2009), 27.
} 
Preliminary research (State of the art) regarding Covid-19 from various aspects has been examined as follows: Jingjing Yuan, Yonglong Lu, Xianghui $\mathrm{Cao}$, and Haotian Cui1 "the association of both outbreaks with wildlife diet in China and proposed suggestions for regulating wildlife conservation and food safety to prevent human exposure to the novel virus, including increasing social awareness of hazards in eating wild animals, strengthening legislation on eating and trading of wild animals, improving the standards for food safety, and establishing market supervision mechanism. Regulatory intervention is not only critical for China but also for other countries where wildife hunting is prevalent to prevent novel virus exposures."

In another aspect research by Roojin Habibi et al. ${ }^{14}$ With findings "First, under Article 43.2, countries cannot implement additional health measures exclusively as a precaution but must rather ground their decision making in scientific principles, scientific evidence, and advice from $W H O$. Second, under Article 43.1, any additional health measures implemented by countries shall not be more restrictive of international traffic and not more invasive or intrusive to persons than reasonably available alternatives, Third. The most importantly, Article 3.1 strictly requires all additional health measures to be implemented "with full respect for the dignity, human rights and fundamental freedoms of persons", which in turn must reflect the international law principles of necessity, legitimacy, and proportionality that govern limitations to and derogations from rights and freedoms".

Alex Ruck Keene Barrister ${ }^{15}$ that "Policies based on protecting the rights of health workers in Covid-19 response services in the form of a future legal framework through normative research with a conceptual approach and laws and regulations."

According to the researches above, the differences in approaches, forms of research and findings in this study are different from previous studies. Thus, it can be inferred that a study on legal protection policies for health workers with Covid-19, the legal protection of health workers during a pandemic is obliged to carry out their duties. Still, on the other hand, they are vulnerable to exposure so that they endanger the health and safety of themselves and those around them. The study will support the policy on the protection of health workers with the responsibilities and obligations of the local

\footnotetext{
${ }^{13}$ Jingjing Yuan, Yonglong Lu, Xianghui Cao, Haotian Cui, "Regulating Wildlife Conservation and Food Safety to Prevent Human Exposure to Novel Virus", Ecosystem Health and Sustainability Journal, Taylor Francis Online 6, no. 1 (2020): 1-4, 2, DOI: 10.1080/20964129.2020.1741325.

14. Roojin Habibi et al., "Do Not violate the International Health Regulations during the COVID-19 Outbreak",NCBC, Lancel February 3995, no. 10225(2020): 664-666, 664, DOI: 10.1016/S0140-6736(20)30373-1.

${ }^{15}$ Alex Ruck Kenee, "Capacity in the time of Coronavirus", International Journal of Law and Psychiatry 70, (2020): 101560, 101565, DOI: 10.1016/j.ijlp.2020.101560.
} 
governments as duty bearers ${ }^{16}$ In the context of the rights of health workers and make everyone safe and healthy by subject to the rules.

Based on the explanation previously stated, it is necessary to conduct a study to examine aspects of the policy for the protection of medical personnel focusing on the Policy for the Protection of Health Workers in Covid-19 Response Services. The development law is needed based on the rights of the health workers and law enforcement to make an effective way to the COVID19 containment measures. The problem in this article is the existing regulations adequate to protect and to fulfil health workers while carrying out Covid-19 response tasks. What does legal framework have to formulate to protect the safety and health of health workers while on duty in outbreaks (Covid-19) containment measures.

In a pandemic outbreak, the application of the law with strict sanctions is important for perpetrators of the COVID-19 protocol. ${ }^{17}$ This research is legal research with a statutory approach. The norms and contents of the legal principles of favourable laws and regulations are analyzed and evaluated whether the regulation of health workers in services during the COVID-19 pandemic is adequate to protect and fulfil the rights of health workers in providing services during a pandemic.

\section{B. Discussions}

\section{Laws and Regulations on the Implementation of Protection of Health Workers during the Covid-19 Containment Measures}

Various laws and regulations relating to the implementation of disaster mitigation, both natural and non-natural disasters have been regulated in the framework of legislation in Indonesia.

\section{a. Act No. 36 of 2009 on Health}

\footnotetext{
16. The principle of fulfilling state obligations emerges as a logical action from the existence of provisions based on international human rights law that individuals are suitable bearers.

Meanwhile, the State has the position of the duty bearer/duty holder of human rights, namely the obligation to protect (to protect), to respect (to respects) and to full fill (to full fill) the human rights of each individual. In fact, according to the provisions of international law, these obligations are obligations ergaomnes (obligation ergaomnes) or an obligation for all countries when it comes to human rights norms which are categorized as Jus Cogens (peremptory norms. See Rhona K Smith et al., Hukum Hak Asasi Manusia (Yogyakarta: Pusham UII, 2012), 24 See also Virgayani Fattah, "Hak Asasi Manusia sebagai Jus Cogens", Jurnal Yuridika 32, no. 2 (2017): 355-378, 366, DOI: 10.20473/ydk.v32i2.4775.

${ }^{17}$ Mohammad Faisol Soleh, "Penimbunan Alat Pelindungan Diripada Masa Pandemi COVID19: Kajian Hukum Pidana Bidang Perlindungan Konsumen”, Undang: Jurnal Hukum 3, no. 1 (2020): 1-31, 12, DOI: 10.22437/ujh.3.1.1-31.
} 
This law states that health is a human right and is one of the elements of welfare as formulated in the Constitution of the Republic of Indonesia. In this law, what is meant by Health Worker is any person who devotes himself to the health sector and has the knowledge and /or skills through education in the health sector which for certain types requires the authority to carry out health efforts. Protection of health workers in this law is stipulated in "Article 27 (1). Health workers have the right to receive compensation and legal protection in carrying out their duties according to their profession. Further provisions regarding legal protection for health workers in this law are not further formulated in the following articles".

\section{b. Act No. 36 of 2014 on Health Workers}

This law is aimed at health workers in Indonesia, which states that health workers have an essential role in improving the quality of health services to the community so that they can create a high degree of health. A high degree of health is an investment for the development of productive human resources, both socially and economically. Health is also seen as a human right that is manifested in the form of providing health services to the community which is carried out comprehensively by the Government, Local Government and the Community in a directed, integrated and sustainable manner, fair and equitable as well as safe, quality and affordable to the community. Health workers who provide services are responsible health workers, have high ethical and moral skills, whose quality needs to be continuously improved through continuous training, certification, registration, licensing, as well as coaching, supervising and monitoring. This law is also intended as the fulfilment of rights and legal certainty for health workers and the community receiving health services.

Article 4 of this Law regulates the responsibility of local governments for the protection of health workers in carrying out their practices. The protection of health workers is further regulated in Part Eight of this Law in Article 75, which stipulates that in carrying out their practice health workers are entitled to legal protection in force.

\section{c. Law No. 29 of 2004 on Medical Practice}

Medical practice is a series of activities performed by doctors and dentists on patients in carrying out health efforts. It is carried out based on Pancasila and based on scientific values, benefits, justice, humanity, balance, and patient protection and safety. It does not regulate legal protection for doctors in carrying out their medical practice.

\section{d. Law No. 38 of 2014 on Nursing}


The activity of providing care to individuals, leaving, groups or communities both in sickness and in a healthy state is called as nursing service. The person who provides such care is called a nurse. ${ }^{18}$ In this law, what is meant by a nurse is someone who has passed higher education in Nursing.

This law is formed to guarantee protection for both the community receiving nursing services and guarantee protection for nurses as nursing service providers. This law not only guarantees legal protection for nurses and nursing service recipients but also regulates the Mutual recognition agreement regarding nursing services in the Southeast Asian region, thereby enabling nurses from foreign countries to enter Indonesia and Indonesian nurses to work outside. In the implementation of nursing services through nursing practice, nurses have the right to legal protection following applicable laws and regulations. ${ }^{19}$

\section{e. Government Regulation No. 67 of 2019 on Management of Health Workers}

According to this provision, a health worker is any person who devotes himself to the health sector and has the knowledge and/or skills through education in the health sector which for certain types requires the authority to carry out health efforts Legal protection for health workers in carrying out their work practices is regulated in Article 87 stated below.

1) In carrying out the practice, the Health Worker has the right to:

a) Obtain legal protection; and

b) Get rewarded.

2) Apart from the rights as referred to in paragraph (1), Health Workers who work in underdeveloped areas of the border and islands, as well as areas with health problems, are also entitled to special promotion and protection in carrying out their duties.

Furthermore, in Article 88:

1) Legal protection for Health Workers is obtained as long as they carry out their duties under professional standards, professional service standards, and standard operating procedures.

2) The legal protection as referred to in paragraph (1) is intended for:

a) Providing legal certainty to Health Workers in providing health services by the provisions of laws and regulations;

b) Guaranteeing to work without coercion and threats from other parties; and

c) Guaranteeing work by authority and professional competence.

3) Legal protection, as referred to in paragraph (1) consists of:

a) Preventive legal protection.

\footnotetext{
${ }^{18}$ Article 1 of the Nursing Law.

${ }^{19}$ Article 36 of Nursing Law
} 
b) Repressive legal protection.

4) Preventive legal protection as referred to in paragraph (3) letter is to ensure legal certainty for Health Workers in carrying out their professional practices and having freedom in carrying out their professional practices.

5) Repressive legal protection as referred to in paragraph (3) letter b is to ensure that Health Workers who have worked under the standards have the opportunity for self-defence and a fair trial process following the provisions of laws and regulations. Legal protection for health workers is more detailed than although it still provides legal protection for health workers in general, there is no regulation on superior legal protection during disasters, especially non-natural disasters.

\section{f. Presidential Regulation of the Republic of Indonesia No. 72 of 2012 on the National Health System}

Health management is a health system carried out by all components of the nation in an integrated and mutually supportive manner in order to achieve a reasonable degree of society. The Public Health System is organized by the Government, Local Government and/ or the Community. Thus, the national health system cannot be implemented maximally with maximum results if it is not carried out jointly and integrated from all related components.

\section{g. Law No. 39 of 1999 on Human Rights}

The right to obtain recognition, guarantee and protection and fair legal treatment and equal treatment before the law is regulated in Article 3 paragraph (2) of this law. Furthermore, in Article 5, paragraph 1 states that every person is recognized as an individual who has the right to demand and receive the same treatment and protection following his human dignity before the law. Various statutory regulations, as described above, show that legal protection for health workers is regulated in legislation. Still, there is no detailed description of the form of legal protection that is regulated.

\section{h. Law No. 24 of 2007 on Disaster Management}

The law on disaster management is essential considering that the territory of the State of Indonesia has geographical, geological, hydrological and demographical conditions that allow disasters to occur whether caused by natural factors, natural factors or human factors, which cause casualties and environmental damage. Loss of property, psychological impact thatis in certain circumstances can hinder national development.

Disasters can be in the form of natural disasters and non-natural disasters. In connection with the Covid-19 pandemic, this is a non-natural disaster. A non-natural disaster is a form of disaster caused by non-natural events or series of events that include technological failure, modernization failure, epidemics 
and disease outbreaks. ${ }^{20}$ Concerning such disasters, a series of actions are required in the context of disaster management, starting with the stipulation of development policies at risk of disasters, activities, disaster prevention, emergency response and rehabilitation. ${ }^{21}$ The local government and regional governments are responsible for disaster management.

The responsibilities of regional governments in implementing disaster management include establishing disaster management policies in their regions in line with regional development policies. The stipulation of this policy is carried out by the Regional Disaster Management Agency that has the task to:

a. Establish guidelines and directives by the policies of the regional government and the National Disaster Management Agency for disaster management efforts covering disaster prevention, emergency response, rehabilitation and reconstruction in a fair and equal manner.

b. Stipulate standardization as well as the need for disaster management based on legislation.

c. Compile, stipulate and inform disaster-prone maps.

d. Prepare and stipulating disaster management routine.

e. Implement disaster management in its area.

f. Report on the implementation of disaster management to the head regional once a month in normal conditions and at any time in a disaster emergency control the collection and distribution of money and goods.

g. Be accountable for the use of the budget received from the revenue budget $\mathrm{d}$ regional shopping.

This statutory regulation is further elaborated in Government Regulation Number 21 of 2008 on Disaster Management.

\section{h. Government Regulation Number 21 of 2008 on Disaster Management}

The Government Regulation is an implementing regulation of Law Number 24 of 2007 on Disaster Management. Article 1 Point 2 states that disaster management is a series of efforts through the establishment of development policies starting from the risk of occurrence of disasters, disaster prevention, emergency response and rehabilitation.

In the aforementioned statutory regulations, several articles have been regulated concerning the protection of health workers in carrying out their professional practices. However, the existing regulations have not explained in detail the various aspects of legal protection through the elaboration of the rights of health workers.

\footnotetext{
${ }^{20}$ Article 1 point 3 of the Disaster Management Law.

${ }^{21}$ Article 1 point 5 of the Disaster Management Law.
} 


\section{Mitigation Policy through Legal Formulation in the Implementation of Covid-19 Pandemic Non-Natural Disaster Management to Protect the Right of Health Workers}

Contact tracing is a common measure to control infectious diseases in the Covid-19. ${ }^{22}$ Individuals who are infected but without symptoms can be a source of infection. This infection can cause mild symptoms such as fever to death. ${ }^{23}$ Legal solutions to address as public health solutions to help mitigate the racialized effects of the disease. ${ }^{24}$

Disaster management through reducing the risk of the impact of natural disasters is regulated in Law Number 24 of 2007 on Disaster Management. This law changes the paradigm of disaster management from initially being responsive, or emergency response after a disaster occurs to disaster management through an emergency response that is preventive so that the risk can be minimized. Article 1 point 9 of Law Number 24 Year 2007, Disaster Mitigation is efforts to reduce disaster risk, both through physical development and awareness and increased capacity to face disaster threats. Furthermore, it is explained in Government Regulation Number 21 of 2008 on Disaster Management in Article 1 paragraph 6 states that disaster management is an implementation of disaster mitigation carried out with several technical steps that need to be conveyed to the public. Hence, this phenomenon is resolved appropriately and does not cause unrest in the middle public.

Based on the understanding of the provisions of the previous articles, disaster mitigation is divided into 2 (two) patterns: (1) Structural mitigation, efforts to minimize disasters carried out through the construction of various physical infrastructure and using a technological approach (such as making impressive canals for flood prevention, equipment detectors of volcanic activity, earthquake-resistant buildings, or an early warning system used to predict the occurrence of tsunami waves), and (2) Non-structural mitigation, efforts to reduce the impact of disasters, apart from physical efforts such as those in structural mitigation.

Disaster mitigation, especially natural disasters, has been carried out reasonably well and in a structured manner in various regions of Indonesia, particularly in areas prone to natural disasters. The Regional Government, through its Regional Regulations, has regulated this disaster mitigation, including in Jambi Province through local government's regulation number 3

\footnotetext{
${ }^{22}$ Hannah van Kohfschoofen, "COVID-19 and Privacy in the European Union: A Legal Perspective on Contact Tracing", Contemporary Security Policy 41, (2020): 478-491, 479, DOI: 10.1080/13523260.2020.1771509.

${ }^{23}$ Nur Indah Fitriani, "Tinjauan Pustaka COVID-19", Jurnal Medikal Malahayati 3, no. 4 (2020): 194-201, 198, DOI: 10.1056/NEJMoa200101.

24 Ruqaiijah Yearby, Seema Mahaputra, "Law, Structural Racism, and the COVID-19 Pandemic", Journal of Law Bioscience 7, no. 1 (2020):1-20, 4, DOI:10.1093/jlb/lsaa036.
} 
of 2016 on the Implementation of Disaster Management. This is a regional policy in dealing with predictable disasters such as forest fires, flood disasters, volcanic eruptions and so on.

Regarding the Covid-19 pandemic, a non-natural disaster that is directly related to health and the prevention of entry and exit of cross-border diseases, it has been regulated in Law Number 6 of 2018 concerning Health Quarantine. First, Article 1 number 1 and number 2 on health quarantine is an effort to prevent and prevent the exit or entry of diseases and/or public health risk factors that have the potential to cause public health emergencies. Second, Public Health Emergencies are public health events of an extraordinary nature characterized by the spread of disease. Infectious and/ or events caused by nuclear radiation, biological pollution, chemical contamination, bioterrorism, and food that pose a health hazard and have the potential to spread across regions or countries. In Article 3, the implementation of Health Quarantine is aimed to protect the public from diseases and/ or Public Health Risk Factors that have the potential to cause a Public Health Emergency, to prevent and prevent disease and/ or Public Health Risk Factors that have the potential to cause a Public Health Emergency, to increase national resilience in the field of public health, and to provide protection and legal certainty for the public and health workers.

However, the question is how about the readiness of the State in implementing the Covid-19 disaster mitigation determined as a non-natural disaster stipulated by Presidential Decree Number 11 of 2020 on Determination of Covid-19 Public Health Emergencies and Presidential Decree Number 12 of 2020 on Determination of Non-Natural Disasters Covid19 as a Non-Natural Disaster. The determination of Covid-19 as a NonNatural Disaster with consideration: ${ }^{25}$

a. Non-natural disasters caused by the spread of Corona Virus Disease 2019 (Covid-19) have had an impact on increasing the number of victims and property losses, expanding the coverage of areas affected by disasters, and having implications for broad socio-economic aspects in Indonesia.

b. The World Health Organization (WHO) has declared COVID-19 a

Global Pandemic on 11 March 2020.

Furthermore, based on this Presidential Decree, covid-19 national nonnatural disaster management is carried out by the Task Force for the Acceleration of Handling Covid-19 through synergy and cooperation with Ministries/Institutions and Regional Governments.

In addition to the Presidential Decree, in the period of the Covid-19 pandemic, various laws and regulations relating to the Covid-19 prevention policy have been issued such as Presidential Decree Number 7 of 2020 in

25 https://www.jogloabang.com/kesehatan/keppres-12-2020-bencana-nonalam-penyebarancovid-19-sebagai-bencana-nasional, Accessed 17 September, 2020. 
conjunction with the Presidential Decree No. 9 of 2020 on the Task Force for the Acceleration of Handling of Corona Virus Disease 2019 (Covid-19), Regulation of the Minister of Law and Human Rights Number 11 of 2020 relating to the temporary prohibition of foreigners from entering/transiting Indonesian territory. Regulation of the Minister of Health Number 9 of 2020 on Guidelines for Large-Scale Social Restrictions in the Context of Accelerating Handling of Corona Virus Diseases 2019 (Covid-19). This regulates guidelines for the mechanism for determining Large-Scale Social Restrictions in implementing Large-Scale Social Restrictions, recording and reporting, and guiding and supervising Large-Scale Social Restrictions. Decree of the Minister of Health Number 612/MENKES/SK/V/2010 on guidelines for implementing health quarantine in the management of public health emergencies is troubling to the world regulates guidelines for health workers from the district hospital (Puskesmas) level to the provincial health office-level regarding the implementation of health quarantine in handling public health emergencies that is troubling the world in preventing the spread of diseases that have a potential public health emergency and could rapidly spread among people through health quarantine activities at entry points and outside national entrances. Circular of the Head of BNPB Number: SE1/BNPB/03/2020 concerning the Establishment of Provincial and Regency/City Level Covid-19 Handling Acceleration Task Forces Regulating the Formation of Provincial and Regency/City Level Covid-19 Handling Acceleration Task Forces. Chief of Police Letter Number: B/2251/Iv/Kep./2020/Pusdokkes, 1 April 2020 Guidelines for self-isolation, is regulated in orders to disseminate self-isolation protocols for handling Covid-19 to the Head of the Health, Health and Social Services of the Police, the Head of the Pusdokkes Polri, the Kabiddokes Polda and the Kapoliklinik Polri.

In the context of tackling the Covid-19 pandemic, the government has taken various policies. The first policy is put forward directly by the President, the policy of maintaining distance, the next step is the policy works from home (WFH) where all work activities are carried out from home. Apart from this WFH policy, the government has also implemented a policy to study from home. All learning processes up to the university level are carried out at home through online learning. This acceptable policy is aimed at inhibiting the spread of covid-19. However, it has various other effects, significantly affecting the economic activities of the community and implications for social activities, including religious activities. For this reason, the government pursued a policy in the form of subsidized assistance packages for economically affected communities. Such policies are still at the level of prevention and removal and have not yet touched the level of prevention and improvement, so they are considered not having an impact on tackling the Covid-19 Pandemic in the long run. 
Policies in the health sector, such as the procurement of emergency hospitals, the fulfilment of PPE (Personal Protective Equipment) needs for health workers. WHO lists Indonesia only has 1.6 beds of ten thousand people. Indonesia has availability of four tens of thousands of doctors, so health service policies tend to be less than optimal in facing the surge in Covid-19 patients. ${ }^{26}$ The task force for the Acceleration of Handling Covid-19 has formulated four strategies in order to accelerate the handling of Covid-19, which are consistently carried out. The First Strategy is Social Distancing; this policy of strengthening distance control is followed by the mandatory policy of wearing masks when in public spaces or outside the house. The second strategy of tracing contacts (tracing) of positive cases is using a rapid test. The third strategy is education about preparing self-isolation on tracking results that show reactive to the possibility of this virus. The immediate strategy is hospital isolation if self-isolation is not possible because there are medical indications that require hospital services. ${ }^{27}$

Various policies have been pursued, but the development of Covid-19 in Indonesia is getting more and more massive. As of 20 September in 2020, a total of 244,676 cases were confirmed positive in Indonesia, with deaths reaching 9,553 cases or $3.9 \%$, a $72.5 \%$ cure rate. ${ }^{28}$ This condition shows that the development of virus infections is increasing day by day, and this requires the government to formulate a policy strategy including a policy strategy for legal formulation in order to prevent the spread of Covid-19 effectively.

The Covid-19 pandemic disaster is massive and has an impact on almost all aspects of life, not only on health aspect but also on economic, social and cultural aspects that gave concern for the community, especially concerns about health safety including among medical and health workers. Amid fears of health safety, health workers are still required to carry out their obligations. As the Code of Ethics, health workers are required to prioritize patient health and pay attention to the interests of public health.

Currently, Indonesia has entered the New Habit Adaptation (IMR) situation or the new average era; this condition results in the potential for the spread of the virus to increase. Therefore, the WHO requires several conditions for a country to be able to establish new habitual adaptation:

a. Countries can show and prove that the transmission of Covid-19 has been controlled,

b. The capacity of the public health system including hospitals is adequate to identify, isolate, test, trace contacts and quarantine patients,

\footnotetext{
$26 \mathrm{https} / / /$ www.balairungpress.com/2020/04/prioritas-kebijakan-pemerintah-indonesia-dalammenangani-pandemi-covid-19/, Accessed 17 September, 2020.

27 https://covid19.go.id/p/berita/empat-strategi-pemerintah-atasi-covid-19, Accessed 17 September, 2020.

28 https://palu.tribunnews.com/2020/09/20/update-covid-19-di-indonesia-total-244676-kasuskonfirmasi-positif-per-minggu-20-september-2020, Accessed on 21 September, 2020.
} 
c. The risk of transmission of the epidemic has been minimized, starting from conditions in high-vulnerability communities such as in nursing homes, mental health patients, and people living in crowded settlements,

d. Preventive measures in the workplace starting to be established such as physical distance, hand washing facilities and respiratory ethics,

e. Import cases can be handled, and

f. The community plays an active role during the transition period (community empowerment). This condition needs to be considered before the government implements the adaptation of new habits.

In fact, after the adoption of new habitual adaptation in Indonesia, the developmental conditions of the spread of Covid-19 increased sharply, surpassing to 3000 new positive cases a day. This condition harms the protection of health workers in Indonesia. During the six months of facing the Covid-19 Pandemic, 181 health workers in Indonesia died, consisting of 115 doctors, 60 of whom were general practitioners, 53 specialist doctors and two resident doctors. Three of the general practitioners and four medical specialists are professors and 69 nurses. Meanwhile, global data recorded 7,000 health workers who died, the highest in Mexico $(1,320)$, the United States (1077), India (573), Brazil (324), South Africa (240). ${ }^{29}$ One of the causes of this high mortality rate for health personnel, according to IDI, is the lack of screening of patients who request services at health facilities. The urgency of screening this patient is needed because the largest percentage of sufferers of Covid-19 are OTG (People Without Symptoms), besides the lack of PPE, the fatigue of health workers due to long working hours and large numbers of patients and psychological pressure.

Protection of hospital occupational safety and health (K3) through the Minister of Health Regulation Number 66 of 2016 states that the hospital is a workplace that has a high risk to the safety and health of hospital human resources, patients, patient companions, visitors, and the home environment. It is necessary to manage and control risks related to occupational safety and health in hospitals in order to create a hospital that is healthy, safe, secure and comfortable.

Working safety is an effort carried out in a structured manner in order to reduce accidents, damage and all forms of harm to humans and those related to equipment, work objects, workplaces and work environment directly or indirectly. Occupational Health is no less important than worker safety, and occupational health is an effort to increase and maintain the highest health status for workers in all positions, prevention of health deviations caused by working conditions, protection of workers from risks due to factors that are detrimental to health, placement and maintenance. Workers in a work

29 https://katadata.co.id/desysetyowati/berita/5f54d3d746195/181-tenaga-medis-meninggalkarena-corona-ikatan-dokter-soroti-pilkada, Accessed on 17 September, 2020. 
environment adapt work to humans and humans with their positions. Occupational safety and health in hospitals are all activities to ensure and protect safety and health for hospital human resources, patients, patient companions, visitors, and the hospital environment through efforts to prevent occupational accidents and occupational diseases in the hospital.

Although various legal regulations regarding the protection of health workers are quite reasonable, efforts to protect health workers cannot stand alone because they should be related to the overall health system. The National Health System according to the Presidential Regulation of the Republic of Indonesia 72 of 2012 concerning the National Health System states that the National Health System is Health Management carried out by all components of the Indonesian nation in an integrated and mutually supportive manner to ensure the attainment of the highest degree of public health. It is implemented in an integrated manner, starting from health administration, health information, health resources, health efforts, health financing, community participation and empowerment carried out in stages at the centre and in the regions by taking into account regional autonomy and functional autonomy in the health sector. The government implements article 4 paragraph (1), the National Health System, local governments, and/or the community, paragraph (2), the National Health System is implemented in a sustainable, systematic, directed, integrated, comprehensive, and responsive manner to changes by maintaining progress, community unity and resilience. According to WHO, the Health System is a network of health service providers (supply side) and people who use these services (demand side) in each region, as well as countries and organizations that give birth to these resources in human and material forms. Then, the system framework in the health sector is an activity to improve the quality of health. Besides, in the implementation of health services in the formal sector, in professionally providing medical assistance, there are firm boundaries between medical treatment and traditional alternative measures.

The current condition for handling Covid-19 shows that the national health system has not been running well, it is necessary to reform the national health system, especially reforms in the field of providing health and pharmaceutical facilities such as medical devices, laboratories and isolation rooms. ${ }^{30}$ In the framework of reforming the national health system, the Ministry of National Development Planning/Bappenas through the Government Work Plan (RKP) 2021 in the health sector focuses on 3 (three) things as follows: 
a. A healthy life movement that includes the provision of clean water, sanitation, washing hands with soap, exercise, environmental health and a healthy area.

b. The ability to prevent, detect and respond by strengthening entrances from abroad through a dangerous disease check system, through foreign entrances and early warning systems.

c. Strengthening of resources, namely covering pharmaceutical facilities for medical devices and human resources for health.

To accelerate the recovery of the COVID-19 outbreak, the Government of Republic Indonesia has appealed to the public with various regulation dan circulations. Being aware of government appeal is considered the best way to slow the spread of the virus. ${ }^{31}$

Responding to the massive spread of covid-19 and seeing the increasing number of health workers exposed to covid-19, in August 2020, the Doctor Mitigation Team in the Covid-19 Pandemic, the Indonesian Doctors Association prepared a Standard Guidelines for Doctor Protection in the Covid-19 Pandemic Era.

In Part Eight of Law Number 36 Year 2014 concerning Health Workers in Article 75 , which regulates that health workers in carrying out their practice are entitled to legal protection in force. Then, it is outlined in Government Regulation Number 67 of 2019 concerning Management of Health Workers, in particular Article 87 and Article 88. Article 3 of Law Number 6 Year 2018 on Health Quarantine as referred to in letter d, one of the objectives of this law is to provide protection and legal certainty for the public and health workers.

From the principle or relationship of patient-doctor (other health workers)hospital, it is known as a therapeutic relationship or therapeutic transaction. ${ }^{32}$ Where there is a contractual agreement (although not written) between the patient and the doctor in terms of treatment and treatment of the disease and between the patient and the hospital in terms of health services by providing standardized facilities and infrastructure. Medical action is a professional action by a doctor against a patient to maintain, improve, restoring health or eliminating or reducing suffering. ${ }^{33}$

Protection of health workers is only regulated in these articles. However, it is still general, and there is no further explanation regarding the protection of health workers during disasters, especially non-natural disasters. Consequently, this requires the further elaboration of the rights and legal

\footnotetext{
${ }^{31}$ Busrol Chabibi, Irfan Jamallullail, "Are Government Appeals on Physical Distancing During the Covid-19 Pandemic Effective? An Analysis from Law and Public Policy”, Journal of Law and Legal Reform 1, no. 4 (2020): 549-562, 549, DOI: 10.15294/jllr.v1i4.39890.

${ }^{32}$ Bahder Johan Nasution, Hukum Kesehatandan Pertanggungjawaban Dokter (Jakarta: Rineka Cipta, 2008), 11.

33 Samsi Jacobalis, Perkembangan Ilmu Kedokteran, Etika Medis, dan Bioetika (Jakarta: Sagung Setobe kerjasama dengan Universitas Tarumanegara, 2005), 49.
} 
protection of health workers in Indonesia, one of which is which can be done by the Regional Government through the Regional Regulation on the Protection of Health Workers in practising during the pandemic. This is in line with the provisions of Article 9 of Law Number 24 of 2007 concerning Disaster Management in which the responsibility of local governments in implementing disaster management includes establishing disaster management policies in their regions in line with regional development policies.

Mitigation efforts to protect health workers cannot stand alone because it cannot be separated from the number of cases that must be controlled. Care and public health systems in all countries must be prepared for emergencies or disasters. Still, if the number of COVID-19 cases increases and exceeds the capacity of the existing health system over a long period, the health system may eventually collapse. If this happens, there will be many victims from health workers including doctors, hospitals are no longer able to accommodate excessive patients, the referral system becomes chaotic, medicines run out, and it can cause other social impacts. Therefore, there needs to support from the government and the community to break this chain of transmission by maintaining and complying with the Large-Periodic Social Restrictions (PSBB) rules and regional quarantine as stated in Law number 6 of 2018 concerning health quarantine. With efforts to break the chain of transmission, the number of cases curve can decrease, allowing the health system to cope with the pandemic.

There are international law instruments to protect health workers. The right to health is a fundamental part of our human rights and our understanding of a life in dignity and prosperity. The patients' right is a human right and comes from individual fundamental rights, the right of self-determination. ${ }^{34}$

The right to the enjoyment of the highest attainable standard of physical and mental health, to give it its full name, is not new. Internationally, it was first articulated in the 1946 Constitution of the World Health Organization (WHO), whose preamble defines health as "a state of complete physical, mental and social well-being and not merely the absence of disease or infirmity". The preamble further states that "the enjoyment of the highest attainable standard of health is one of the fundamental rights of every human being without distinction of race, religion, political belief, economic or social condition." 35 "The 1948 Universal Declaration of Human Rights also mentioned health as part of the right to an adequate standard of living which is regulated in Article 25. The right to health was again recognized as a human

\footnotetext{
${ }^{34}$ Hermien Hadiati Koeswadji, Hukum dan Masalah Medik (Surabaya: Airlangga University Press, 1984), 47

35 Johannes Thome et al., "The Impact of COVID-19 Outbreaks on the Medico Legal and Human Rights on Phylactery Patients", European Psychiatry 63, no. 1 (2020): 1-2, 1, DOI: 10.1192/j.eurpsy.2020.58.
} 
right in the 1966 International Covenant on Economic, Social and Cultural Rights. Since then, other international human rights treaties have recognized or referred to the right to health or to elements of it, such as the right to medical care. The right to health is relevant to all States: every State has ratified at least one international human rights treaty recognizing the right to health. Moreover, States have committed themselves to protect this right through international declarations, domestic legislation and policies, and at international conferences".

International Health Regulation (2005) have The purpose and scope "to prevent, protect against, control and provide a public health response to the international spread of disease in ways that are commensurate with and restricted to public health risks, and which avoid unnecessary interference with international traffic and trade." State Party obligations to develop specific minimum core public health capacities, including legal policy. "The right to health is protected under the International Covenant on Economic, Social and Cultural Rights (ICESCR), ratified by Indonesia through Act No. 11 of 2005".

The ICESCR requires state parties to achieve full implementation of the right to health, including "prevention, treatment and control of epidemic, endemic, occupational and other diseases". "ICESCR also protects the right of everyone to the enjoyment of just and favourable conditions of work which includes safe and healthy working conditions".

"The best outbreak response is a collective response (Gille\&Brall, 2020), which could effectively contain the disease and the panic caused by the disease". ${ }^{36}$ One way of doing this can be through law enforcement of the Covid-19 protocol with the regulatory substances to enforce the protocol Covid-19 that everyone is required to comply with the Covid-19 Protocol when in public places, every health worker has the right to receive protection when carrying out health care duties for patients infected with Covid-19. Local Governments, Heads of Government Agencies, Private Business Entities, must implement the Covid-19 Protocol by providing a place to wash hands before the entrance and other strategic places outside and inside the building. The important one before the vaccine has found make regulation everyone who violates the Covid-19 Protocol not wearing a mask in public places/facilities will be subject to a fine.

By designing the substances in the local regulation that will apply to everyone per higher regulatory orders, this policy is adequate and relevant in preventing the spread of the virus from protecting health workers in the Covid19 containment measures and the broader community as a whole. The regional regulation emphasizes the obligation to wear a mask and the punishment that will be received if this regulation is violated as a deterrent effect.

\footnotetext{
${ }^{36}$ Connie CR Gan, et al., "How Can The Public be Better Protected Against Covid-19?", Jurnal Berkala Epidemiologi 8, no. 2 (2020): 97-99, 98, DOI: 10.20473/jbe.v8i22020.97-99.
} 


\section{Conclusion}

The laws and regulations in Indonesia regarding disaster mitigation and protection for health workers have been regulated in various laws and regulations such as in Part Eight of Law Number 36 of 2014 on Health Workers, in Article 75 and Article 3 of Law Number 6 of 2018 on Health Quarantine in letter d, Government Regulation Number 67 Year 2019 on Management of Health Workers, Article 88 on Regulations for the protection of health workers as regulated in the current legislation. They are still general. Regulations regarding the protection of health personnel, especially during disasters, both natural and non-natural disasters such as the current pandemic, have not been adequately regulated.

The Covid-19 pandemic has made all countries especially Indonesia awareness of the vital role played by Health workers in saving the lives of patients infected with Covid-19. No country, hospital or clinic can keep its patients safe unless health workers are kept safe and sound. Steps to ensure that health workers have safe working conditions is to ensure all rights are fulfilled.

\section{Suggestion}

Referring to Article 9 of Law Number 24 of 2007 concerning Disaster Management where the responsibility of the Regional Government in carrying out disaster management includes establishing disaster management policies in their areas in line with regional development policies. It is appropriate for the Regional Government to create policies through the formation of Regional Regulations as an effort to mitigate the protection of health workers and people in the region.

\section{References}

Chabibi, Busrol., Jamallullail, Irfan. "Are Government Appeals on Physical Distancing During the Covid-19 Pandemic Effective? An Analysis from Law and Public Policy", Journal of Law and Legal Reform 1, no. 4, 2020: 549-562, DOI: 10.15294/jllr.v1i4.39890.

Fattah, Virgayani. "Hak Asasi Manusia sebagai Jus Cogens", Jurnal Yuridika 32, no. 2, 2017: 355-378, DOI: 10.20473/ydk.v32i2.4775.

Fitriani, Nur Indah. "TinjauanPustaka COVID-19", Jurnal Medikal Malahayati 3, no. 4, 2020: 194-201, DOI: 10.1056/NEJMoa200101.

Gan, Connie CR.,et al., "How Can The Public be Better Protected Against Covid-19?", Jurnal Berkala Epidemiologi 8, no. 2, 2020: 97-99, 98, DOI: 10.20473/jbe.v8i22020.97-99.

Government Regulation Number 67 of 2019 concerning Management of Health Workers 
Habibi, Roojinet al., "Do Not violate the International Health Regulations during the COVID-19 Outbreak", NCBC, The Lancel 3995, no. 10225, 2020: 664-666, 664, DOI: 10.1016/S0140-6736(20)30373-1.

Haryani, Syafitri. SengketaMedis: Alternatif Penyelesaian antara Dokter dengan Pasien. Jakarta: Diadit Media, 2005.

https://covid19.go.id/p/berita/empat-strategi-pemerintah-atasi-covid-19, Accessed September 17, 2020.

https://katadata.co.id/desysetyowati/berita/5f54d3d746195/181-tenagamedis-meninggal-karena-corona-ikatan-dokter-soroti-pilkada, Accessed on September 17, 2020.

https://palu.tribunnews.com/2020/09/20/update-covid-19-di-indonesia-total244676-kasus-konfirmasi-positif-per-minggu-20-september-2020, Accessed on September 21, 2020.

https://www.balairungpress.com/2020/04/prioritas-kebijakan-pemerintahindonesia-dalam-menangani-pandemi-covid-19/, Accessed September 17, 2020.

https://www.jogloabang.com/kesehatan/keppres-12-2020-bencana-nonalampenyebaran-covid-19-sebagai-bencana-nasional, Accessed September 17, 2020.

https://www.kompas.com/tren/read/2020/03/06/173000265/infografik--6kelompok-orang-yang-rentan-terinfeksi-virus-corona, Accessed onApril19, 2020.

https://www.kompas.com/tren/read/2020/04/17/155100565/46-tenagakesehatan-di-semarang-positif-covid-19-ini-harapan-persatuanperawat-?page=all, Accessed on April 17, 2020.

https://www.liputan6.com/bisnis/read/4242023/pemerintah-akui-sistemkesehatan-indonesia-belum-kuat-hadapi-covid-19, Accessed September 17, 2020.

https://www.liputan6.com/news/read/4224721/161-tenaga-kesehatan-dijakarta-positif-covid-19, Accessed on April 17, 2020

https://www.tempo.co/bbc/5990/kisah-tenaga-kesehatan-yang-hadapiwabah-virus-corona-di-empat-negara-maju-bagaimana-kami-tidaktakut, Accessed onApril19, 2020.

Jacobalis, Samsi. Perkembangan Ilmu Kedokteran, Etika Medis, dan Bioetika. Jakarta: Sagung Seto bekerjasama dengan Universitas Tarumanegara, 2005.

Jin, Hoa., et al."Complex Emergency of Covid 19 Management and Experience in Zhuhai China", International Journal Antimicrobacterial Agent 55, no. 5 2020: 105961, 105962, DOI: 10.1016/j.ijantimicag.2020.105961

Koeswadji, Hermien Hadiati. Hukum dan Masalah Medik. Surabaya: Airlangga University Press, 1984. 
Kohfschoofen, Hannah van. "COVID-19 and Privacy in the European Union: A Legal Perspective on Contact Tracing".Contemporary Security Policy 41, no. 2020: 478-491, DOI: 10.1080/13523260.2020.1771509.

Law Number 24 of 2007 concerning Disaster Management, State Gazette of the Republic of Indonesia Number 66 of 2007.

Law Number 36 of 2014 concerning Health Workers, State Gazette of the Republic of Indonesia Number 298of 2014.

Law Number 36 of 2014 concerning Nursing, State Gazette of the Republic of Indonesia of 2014 Number 2007.

Marzuki, Peter Mahmud. Penelitian Hukum. Jakarta: Kencana, Prenada Media, 2005.

Nasution, Bahder Johan. Hukum Kesehatan Pertanggungjawaban Dokter. Bandung: Rineka Cipta, 2008.

Parmet, Wendy E. Quarantining the Law of Quarantine: Why Quarantine Law Does Not Reflect Contemporary Constitutional Law. 2018.

Petersen, Eskild., et al., "Covid-19 Travel Restriction and The International Health Regulation", International Journal of Infectious Diseases 94, 2020: 88-90, DOI: 10.1016/j.ijid.2020.04.029 1201-9712/Crown.

Presidential Decree 12/2020 concerning the National Disaster Nonalam Coronavirus disease / Covid 19.

Shaw, Rajib.,et al. "Governance, Citizen and Behaviour in Pandemic Lesson from east Asia", Journal Progress in Disaster Science 6, 2020: 10009, DOI: 10.1016/j.pdisas.2020.100090.

Sidharta, Bernard Arief. Refleksi tentang Struktur Ilmu Hukum. Bandung: Mandar Maju, 2009.

Smith, Rhona K., et al. Hukum Hak Asasi Manusia. Yogyakarta: Pusham UII, 2012.

Soleh, Mohammad Faisol."Penimbunan Alat Pelindungan Diri pada Masa Pandemi COVID-19: Kajian Hukum Pidana Bidang Perlindungan Konsumen". Undang: Jurnal Hukum 3, no. 1, 2020: 1-31, DOI: 10.22437/ujh.3.1.1-31.

Thome, Johannes.,et al. "The Impact of COVID-19 Outbreaks on the Medico Legal and Human Rights on Phylactery Patients", European Psychiatry 63, no. 1, 2020: 1-2, DOI: $10.1192 /$ j.eurpsy.2020.58.

USAID. Rights in Time of The Covid The Key of Human Right and Fundamental Principle. 2020.

Yearby, Ruqaiijah., Mahaputra, Seema. "Law, Structural Racism, and the COVID-19 Pandemic", Journal of Law Bioscience 7, no. 1, 2020: 120, DOI:10.1093/jlb/lsaa036.

Yuan, Jingjing., et al. "Regulating Wildlife Conservation and Food Safety to Prevent Human Exposure to Novel Virus", Ecosystem Health and Sustainability Journal, Taylor Francis Online 6, no. 1, 2020: 1-4, DOI: 10.1080/20964129.2020.1741325. 
